\title{
Overview of Patients with Multiple Primary Tumors During Eighty-four Months Follow-up: A Single Center Experience
}

\section{Seksen-dört Aylık İzlemde Çoklu Primer Tümör Tanılı Hastalarımıza Bakış: Tek Merkez Deneyimi}

\author{
(1) Özlem Mermut ${ }^{1}$, (D) Rıza Umar Gürsu² \\ 1istanbul Training and Research Hospital, Clinic of Radiation Oncology, Istanbul, Turkey \\ 2istanbul Training and Research Hospital, Clinic of Medical Oncology, İstanbul, Turkey
}

\begin{abstract}
Introduction: Advances in oncological diagnosis and treatment increase survival and remission of the disease. However, prolonged survival also increases the likelihood of developing second primary malignancies. The aim of this article was to evaluate whether the second primary tumor is associated with the first primary tumor and to determine the survival time in patients diagnosed with cancer, treated, and followed-up, and to make recommendations about the follow-up of these patients.

Methods: Patients who were admitted to the İstanbul Training and Research Hospital, Clinic of Radiation Oncology and Medical Oncology, between January 2011 and December 2017, and who had a follow-up of more than 6 months were retrospectively reviewed. Of 9892 patients, multiple primary tumors (MPT) were detected in 121 patients. The origin of tumor, occurrence time, gender, age, metastasis and survival rates of the patients were investigated. Data were collected using Excel and transferred to SPSS 22.0 program.

Results: There were 56 (46\%) female and 65 (54\%) male patients. The mean age of the female patients was 58 years and the mean age of the male patients were 64 years. The median age for both sexes was 63 (range: 37-82). The second primary tumor was found to be metachronous in 89 patients (74\%) and synchronous in 32 patients (26\%). The incidence of MPT was $1.22 \%$. Breast-breast cancer pair in women and larynx-lung cancer pair in men were in the foreground. Eighty-one patients (67\%) had a history of smoking and 18 patients (15\%) had a history of alcohol use. In synchronous and metachronous tumors, the most common metastasis was observed in the skeletal system. Median overall survival was 51 months in synchronous tumors and 72 months in metachronous tumors.

Conclusion: The development of a second primary cancer in a patient diagnosed with cancer is higher than in those who have not been diagnosed with cancer. Early diagnosis of patients and prolongation of survival may increase the incidence of second primary tumors. For this reason, new complaints emerging
\end{abstract}

öz

Amaç: Onkolojik tanı ve tedavilerdeki gelișmeler sağkalımı artırmakta ve hastalığın remisyonunu sağlamaktadır. Bununla birlikte uzamış sağkalım ikincil primer malignitelerin gelişmesi olasııı̆ını da artırmaktadır. Bu makalenin amacı kanser tanısı konulmuş, tedavi almış ve takip edilen hastalarda ikinci tümörün birinci tümörle ilişkili olup olmadığını ve sağkalım sürelerini değerlendirmek, bu hastaların takibinde neler yapılabileceği konusunda önerilerde bulunmaktır.

Yöntemler: Ocak 2011 ile Aralık 2017 tarihleri arasında, İstanbul Eğitim ve Araştırma Hastanesi Radyasyon Onkolojisi ve Tıbbi Onkoloji polikliniklerine başvuran, 6 aydan uzun süreli takipleri olan, 9892 hasta dosyası retrospektif olarak incelendi. Yüz yirmi bir hastada multiple primer tümör (MPT) olduğu saptandı. Tümörün hangi organlarda oluştuğu, ne zaman geliștiği, hastaların cinsiyeti, yașı, metastaz, sağkalım oranları araștırıldı. Veriler Excel'de toplanarak SPSS 22.0 programına aktarıldı.

Bulgular: 56 (\%46) kadın, 65 (\%54) erkek hasta vardı. Kadın hastaların yaş ortalaması 58, erkek hastaların ise 64 olarak bulundu. Her iki cins için ortanca yaş 63 (37-82) olarak tespit edildi. Hastaların 89'unda (\%74) ikinci tümör metakron, 32'sinde (\%26) senkron olarak saptandı. Çoklu MPT görülme oranımız \%1,22 idi. Kadınlarda meme-meme kanseri; erkelerde larenks-akciğer kanseri çiftleri ön planda gözlendi. 81 (\%67) hastada sigara içme öyküsü; 18 (\%15) hastada alkol kullanma alıșkanlığı öyküsü vardı. Senkron ve metakron tümörlerde en sık metastaz iskelet sisteminde gözlendi. Senkron tümörlerde medyan genel sağkalım 51 ay, metakron tümörlerde 72 ay olarak saptandı.

Sonuç: Kanser tanısı almış bir hastada ikinci bir kanser gelișimi, kanser tanısı almamıș kimselere göre daha fazladır. Hastaların erken teșhis edilmesi ve sağkalımın uzaması ile ikincil tümöre yakalanma sıklığı artabilmektedir. Bu nedenle kanser tanısı almış hastaların takipleri sırasında ortaya çıkan 
during the follow-up of patients diagnosed with cancer should be considered and second primary tumors should be suspected. We think that long-term follow-up, especially for detecting early metachronous tumors, will contribute to survival in patients with cancer.

Keywords: Multiple primary tumors, synchronous, metachronous yeni yakınmalar önemsenmeli ve ikincil tümörler göz önünde bulundurulmalıdır. Özelikle metakron tümörleri erken saptamak için kanserli hastalarda uzun süreli takibin sağkalıma katkısı olacağını düşünüyoruz.

Anahtar Kelimeler: Çoklu primer tümör, senkron, metakron

\section{Introduction}

Advances in oncologic diagnosis and treatment increase survival and remission of the disease. However, prolonged survival increases the likelihood of developing second primary malignancies. The term "multiple primary malignant tumors" was first used by Billroth in 1889, and the first paper describing multiple primary tumors (MPT) was published by Warren and Gates in 1932 (1,2). According to today's definition, the features that should be available in MTPs are: 1) Each tumor should be diagnosed as malignant histopathologically, 2) each tumor should be histopathologically different tumors, and 3) each tumor should not be recurrence or metastasis of other tumor. While synchronous tumors are defined as tumors seen within 6 months after primary tumor diagnosis, metachronous tumors are tumors diagnosed after 6 months of primary tumor diagnosis (2). Although the mechanism of occurrence cannot be determined exactly, genetic mutations, chemotherapy and/or radiotherapy applications and prolonged survival of cancer patients are known to increase the risk of second primary tumor development (3-6).

The aim of this article was to evaluate whether the second primary tumor is associated with the primary tumor in patients who were treated and followed-up with cancer diagnosis, to evaluate the survival time and to make recommendations about the follow-up of these patients.

\section{Methods}

The files of 9892 patients who were followed for more than 6 months in Radiation Oncology and Medical Oncology clinics between January 2011 and December 2017 were examined. One hundred and twentyone patients with primary tumors diagnosed as having synchronous or metachronous tumors were included in the study. The incidence of MPT was $1.22 \%$. Patients with $\geq$ primary tumors and those who had been diagnosed with cancer for the first time in more than 7 years were excluded from the study. Overall survival (OS) was defined as the time from diagnosis to last follow-up or death. The data about whether the patients were alive or not were obtained from the computer system of our hospital. Patient case report forms and consent are included in each patient's file. Approval was obtained from the İstanbul Training and Research Ethics Committee of our hospital (decision no: 1628, date: 04.01.2019).

\section{Statistical Analysis}

Data were collected in Excel and transferred to SPSS 22.0 program. Mean, standard deviation, median, minimum, maximum, frequency and percentage values were used in statistical analysis. The definition of the variables was measured by the Kolmogorov Smirnov test. The chi-square test was used for the analysis of qualitative independent data, and Fisher's Exact test was used when the chi-square conditions were not met. Independent sample t-test was used for the analysis of quantitative independent data. Kaplan-Meier log-rank test was used for survival analysis.

\section{Results}

Of 121 patients, 56 (46\%) were female and 65 (54\%) were male. The mean age of the female patients was $58 \pm 10.37$ years and the mean age of the male patients was $64 \pm 8.62$ years. The median age for both sexes was 63 (37-82) years. The second primary tumor was found to be metachronous in 89 patients $(74 \%)$ and synchronous in 32 patients (26\%). The time between the detection of the first and second primary tumors was 1.1 months (range: $0-6$ ) in synchronous tumors and 30.8 months (range: 7-78) in metachronous tumors. Eighty-one patients (67\%) had a history of smoking and 18 patients (15\%) had a history of alcohol use.

In 32 patients with synchronous tumors, breast cancer/breast cancer pair was the most common tumor pair (38\%), followed by breast cancer/ colorectal cancer pair (13\%). Among 89 patients with metachronous tumor, laryngeal cancer/lung cancer was the most common tumor pair (13\%), followed by prostate cancer/lung cancer (8\%). When MPTs were evaluated histopathologically, invasive ductal carcinoma/invasive lobular carcinoma was most common in synchronous tumors, whereas adenocarcinoma was the most common carcinoma in metachronous tumors, followed by epidermoid carcinoma.

The metastasis was observed after a mean period of $15(4.78 \pm 11.29)$

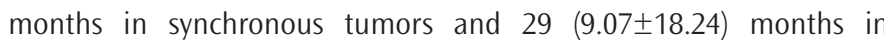
metachronous tumors. The most common site of metastasis was observed as skeletal system in four (40\%) patients with synchronous tumor and in nine (36\%) patients with metachronous tumor $(p=0.126)$. Demographic characteristics of patients with synchronous and metachronous tumors are shown in Table 1.

In our study, the most common tumor in women was found to be breast cancer (64\%) and the second most common tumor was colorectal cancer (14\%). In men, laryngeal cancer (25\%) was the most common cancer followed by prostate cancer (17\%). Tumor pairs were breast-breast and breast-colorectal in women, and larynx-lung and prostate-lung in men. The distribution of tumors by gender is shown in Table 2 .

In our study, surgery for synchronous tumors was performed in 25 patients (78\%). Then, the curative treatment of the patients was determined starting from the tumor, whichever of the diseases would determine the survey. The curative treatment was performed to primary tumor in 82 patients (92\%) with metachronous tumors. Median OS was 51 (95\% confidence interval (CI): 43.69-58.30) months for synchronous 
tumors and $72(95 \%$ Cl: 59.44-84.55) months for metachronous tumors (log rank: 0.145). General survival graphs of synchronous and metachronous tumors are shown in Figure 1.

\section{Table 1. Demographic distribution of synchronous and metachronous tumors}

\begin{tabular}{|c|c|c|c|}
\hline & $\begin{array}{l}\text { Synchronous } \\
\text { tumor, } \\
n=32(26 \%)\end{array}$ & $\begin{array}{l}\text { Metachronous } \\
\text { tumor, } \\
\mathrm{n}=89(74 \%)\end{array}$ & $\mathbf{p}$ \\
\hline \multicolumn{4}{|l|}{ Gender } \\
\hline Female & $24(75)$ & $32(36)$ & \multirow{2}{*}{$<0.001$} \\
\hline Male & $8(25)$ & $57(64)$ & \\
\hline \multicolumn{4}{|l|}{ Smoking } \\
\hline Smoker & $19(59)$ & $62(70)$ & \multirow{2}{*}{0.289} \\
\hline Non-smoker & $13(41)$ & $27(30)$ & \\
\hline \multicolumn{4}{|l|}{ Alcohol use } \\
\hline Yes & $1(3)$ & $17(19)$ & \multirow{2}{*}{0.029} \\
\hline No & $31(97)$ & $72(81)$ & \\
\hline \multicolumn{4}{|l|}{ Metastasis } \\
\hline Present & $10(31)$ & $26(29)$ & \multirow{2}{*}{0.829} \\
\hline Absent & $22(69)$ & $63(71)$ & \\
\hline \multicolumn{4}{|l|}{ 1. Primary } \\
\hline \multicolumn{4}{|l|}{ Localization $^{1}$} \\
\hline Breast & $18(56)$ & $21(24)$ & \multirow{4}{*}{0.002} \\
\hline Colorectal & $5(16)$ & $12(14)$ & \\
\hline Larynx & - & $16(18)$ & \\
\hline Other & $9(28)$ & $40(45)$ & \\
\hline \multicolumn{4}{|l|}{ Histopathology ${ }^{1}$} \\
\hline Adenocarcinoma & $11(34)$ & $29(33)$ & \multirow{4}{*}{0.003} \\
\hline IDC/ILC & $17(53)$ & $21(24)$ & \\
\hline SCC & $1(3)$ & $24(27)$ & \\
\hline Other & $3(9)$ & $15(17)$ & \\
\hline \multicolumn{4}{|l|}{ Stage $^{1}$} \\
\hline Stage 1-2 & $21(66)$ & $61(69)$ & \multirow{2}{*}{0.762} \\
\hline Stage 3-4 & $11(34)$ & $28(31)$ & \\
\hline
\end{tabular}

\section{Primer}

\section{Localization ${ }^{2}$}

\begin{tabular}{|l|l|l|l|}
\hline Breast & $16(50)$ & $15(17)$ & \multirow{2}{*}{0.001} \\
\hline Lung & $2(6)$ & $29(33)$ & \\
\hline $\begin{array}{l}\text { Colorectal } \\
\text { Other }\end{array}$ & $3(9)$ & $7(8)$ & \\
\hline Histopathology & $11(34)$ & $38(43)$ & \\
\hline Adenocarcinoma & $8(25)$ & $27(30)$ & 0.001 \\
\hline IDC/ILC & $16(50)$ & $15(27)$ & \\
\hline SCC & $2(6)$ & $24(27)$ & \\
\hline Other & $6(19)$ & $23(26)$ & \\
\hline Stage & & & \\
\hline Stage 1-2 & $21(66)$ & $54(61)$ & 0.621 \\
\hline Stage 3-4 & $11(34)$ & $35(39)$ & \\
\hline Hiss pin) & & & \\
\hline
\end{tabular}

${ }^{1}$ first primary tumor, ${ }^{2}$ Second primary tumor, IDC/ILC: invasive ductal carcinoma/ invasive lobular carcinoma, SCC: squamous cell carcinoma
Table 2. Gender distribution of most common tumor, histopathology and stage

\begin{tabular}{l|l}
$\begin{array}{l}\text { Female, } n=56 \\
(46 \%)\end{array}$ & $\begin{array}{l}\text { Male, } n=65 \\
(54 \%)\end{array}$
\end{tabular}

\section{Localization ${ }^{1}$}

Breast

Colorectal

Larynx

Gynecological

Prostate/bladder

Other

$36(64)$

$(54 \%)$

p

\begin{tabular}{|l|l|}
\hline Histopathology & $6(11)$ \\
\hline
\end{tabular}

Adenocarcinoma

IDC/ILC

SCC

$34(60)$

$3(5)$

Other

2 (4)

9 (14)

8 (14)

$16(25)$

$<0.001$

\section{Stage ${ }^{1}$}

Stage 1-2

Stage 3-4

$4(7)$

$0 / 2(0 / 4)$

$11 / 6(17 / 9)$

$20(30)$

$26(40)$

4 (6)

$23(35)$

$12(19)$

\section{Localization $^{2}$}

\begin{tabular}{|l|l|l|l|}
\hline Breast & $30(54)$ & $1(2)$ & \\
\hline Lung & $4(7)$ & $27(42)$ & $<0.001$ \\
\hline Colorectal & $5(9)$ & $5(8)$ & \\
\hline Prostate/bladder & - & $8 / 2(12 / 3)$ & \\
\hline Other & $17(30)$ & $22(33)$ & \\
\hline
\end{tabular}

\section{Histopathology $y^{2}$}

Adenocarcinoma

IDC/ILC

$\mathrm{SCC}$

13 (23)

22 (34)

seC 3

30 (54)

1 (2)

Other

$3(5)$

23 (35)

0.065

\section{Stage $^{2}$}

\section{Stage 1-2}

$10(18)$

$19(29)$

Stage 3-4

39 (70)

17 (30)

36 (55)

29 (45)

0.109

${ }^{1}$ first primary tumor, ${ }^{2}$ second primary tumor, IDC/ILC: invasive ductal carcinoma/invasive lobular carcinoma, SCC: squamous cell carcinoma

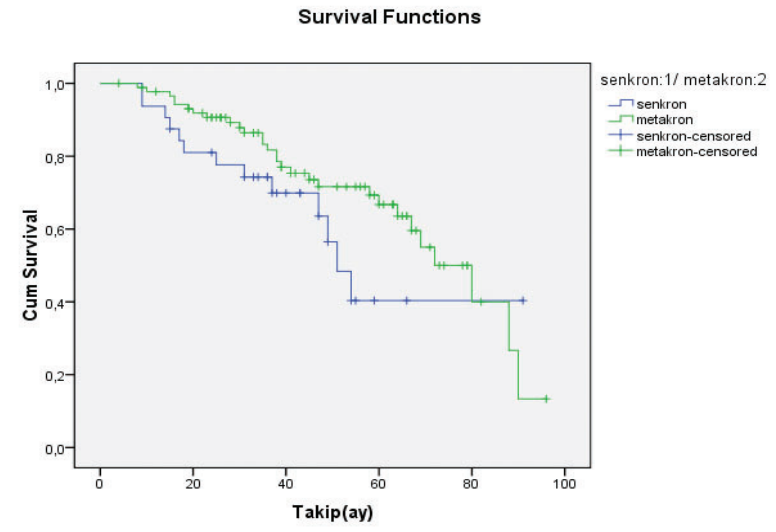

Figure 1. Overall survival in synchronous and metachronous tumors 


\section{Discussion}

We see that the number of patients diagnosed with cancer at an early stage has increased with the increased use of screening programs and that the survival of patients has been prolonged with new treatments developed. With long survival times, the probability of developing a second primary tumor increases. Metachronous tumors often develop as a result of previous cancer treatments such as chemotherapy and radiotherapy, whereas synchronous tumors are associated with organspecific carcinogens such as cigarettes and alcohol (3). The development of a second cancer in a patient diagnosed with cancer is 1.29 times higher than in patients with no diagnosed cancer (4). This is due to cancer development in different organs as a result of exposure to the same carcinogens in the primary tumor site (such as smoking, alcohol use) or genetic changes $(7,8)$. Smoking and alcohol use can also trigger a second cancer in the lung, esophagus, pancreas, cervix and bladder. This condition is called "field cancerization effect" (9-11). Thirty-three patients (27.2\%) in our study had the first tumor diagnosis in these organs.

MPTs can occur at any age, but they are reported to be more common after the age of 50 (12-14). The median age of our patients was 63 (37-82) and was consistent with the literature. We can attribute the incidence of MPT in advanced age to weakening of immunity with aging, prolongation of exposure to carcinogens, and sensitization to carcinogens with aging.

According to surveillance, epidemiology, end results program data, in which annual cancer statistics are published, prostate-respiratory system cancer is the most common tumor pair in men, followed by prostate-colon cancer (primary tumor-second tumor). Breast cancerbreast cancer pair is the most common and breast cancer-colorectal cancer pair is the second most common pair in women (15). In this study, similar to the above data, the most common MPT pair in female patients was breast-breast and breast-colorectal cancer pairs. However, the situation was slightly different in male patients. In men, larynx-lung and prostate-lung cancer were the most common cancer pairs. We think that the difference in male patients is mainly due to the fact that we have more head and neck cancer patients and small number of cases diagnosed with lung cancer. This difference can be explained by the high smoking and alcohol use in male patients.

The male/female ratio in patients with MPTs varies between 0.9 and 3.5 in various publications $(15,16)$. The male/female ratio was 1.1 in our patients and this was consistent with the literature. MPTs are mostly seen as metachronous $(16,17)$. Eighty-nine patients $(73.6 \%)$ in our study had metachronous tumors.

In the literature, the incidence of MPT in genitourinary tumors is reported as $13.5 \%$ (17). In our study, there were 17 patients with genitourinary cancer and this rate was found to be $14 \%$. In a study evaluating the success of Positron-emission tomography/ Computed Tomography (PET/ (T) in the detection of synchronous primary tumor, 9.5\% of patients had synchronous primary tumor, PET/CT detected $84 \%$ of them and treatment changed in $80 \%$ of patients (18). Similar to the other studies, metachronous tumors (76\%) were observed more in our study. However, in contrast to the above study, the incidence of synchronous tumors was higher (36\%). In our study, the contribution of PET/CT in detecting synchronous and metachronous tumors, in the initial staging and in follow-up was significant. Almost all cases were diagnosed in this way.

In terms of prognosis, it is seen that there is a worse survival time in MPT cases especially in synchronous tumors. The reason for this is to fight two cancers in the same period in the synchronous tumor group, whereas the primary tumor is treated in metachronous tumors and the time to development of a second cancer was shown to be longer (19). In our study, the median OS was 51 months in synchronous tumors and 72 months in metachronous tumors.

In the literature, the incidence of MPT varies between $0.4 \%$ and $21 \%$ $(19,20)$. This rate was $1.22 \%$ in our patients. Adenocarcinoma was the most common histological type in one series (21). Similar to the literature, the histology of adenocarcinoma was prominent in 37 patients (31\%) in our study.

While synchronous tumors are caused by exposure to similar carcinogens, the negative effects of the treatments for first tumor can be mentioned on the development of metachronous tumors. The etiology may include the causes of the primary tumor or treatments applied to the primary tumor (22). In our study, 81 patients (67\%) had a history of smoking and 18 (15\%) had a history of alcohol use. Regarding the relationship between synchronous and metachronous tumors with alcohol use and smoking in our study, no difference was found between smoking and development of both tumors, while alcohol use was higher in metachronous tumors. As mentioned above, we could expect more cigarette and alcohol use in synchronous tumors, but this was not observed in this group because synchronous tumor pairs had more breast meme breast carcinomas. We know that smoking and alcohol use are not as intensely related to the etiology of breast tumors, as in head and neck and lung cancers. Laryngeal-lung carcinoma pair was more common in metachronous tumors. The association of this tumor pair is generally associated with smoking and alcohol use. As a result, alcohol use in metachronous tumors was statistically higher in our study.

\section{Conclusion}

Early detection of cancer and prolonged survival may increase the incidence of second primary tumors. For this reason, new complaints emerging during the follow-up of patients diagnosed with cancer should be considered and second primary tumors should be suspected. When metachronous tumor is diagnosed, multidisciplinary approaches may prolong survival in these patients. In addition, patients should be given increased awareness by giving up smoking and alcohol, paying attention to their weight, doing sports, and participating in screening test programs (fecal occult blood test, smear examination, mammography etc.). We think that long-term follow-up will contribute to the survival of patients who have survived more than 5 years, especially for cancers that may develop metachronously.

Ethics Committee Approval: Approval was obtained from the İstanbul Training and Research Ethics Committee of our hospital (decision no: 1628, date: 04.01.2019).

Informed Consent: Patient case report forms and consent are included in each patient's file. 
Peer-review: Externally and internally peer-reviewed.

Author Contributions: Data Collection and/or Processing - Ö.M.; Analysis and/or Interpretation - Ö.M., R.U.G.; Literature Search - Ö.M.; Writing Manuscript - Ö.M.

Conflict of Interest: No conflict of interest was declared by the authors.

Financial Disclosure: The authors declared that this study received no financial support.

\section{References}

1. Warren S, Gates O. Multiple primarymalignant tumors: A survey of the literature and a statistical study. Am J Cancer 1932; 16: 1358-414.

2. Morgenfeld EL, Tognelli F, Gil Deza E, et al. Synchronous and metachronous second (ST) and third (TT) primary tumors (PT) in a large patient population. Proc ASCO 2003; 22: 3152

3. Woodward WA, Strom EA, McNeese MD, Perkins GH, Outlaw EL, Hortobagyi GN. Cardiovascular death and second non-breast cancer malignancy after postmastectomy radiation and doxorubicin-based chemotherapy. Int J Radiat Oncol Biol Phys 2003; 57: 327-35.

4. Shikhani AH, Matonoski GM, Jones MM, Kashima HK, Johns ME Multipleprimary malignandes in head and neckcancer. Arch Otolaryngol Head Neck Surg1986; 112: 1172-5.

5. Carmichael AR, Bendall S, Lockerbie L, Prescott R, Bates T. The long-term outcome of synchronous bilateral breast cancer is worse than metachronous or unilateral tumours. Eur J Surg Oncol 2002; 28: 388-91.

6. Hemminki K, Boffetta P. Multiple primary cancers as clues to environmental and heritable causes of cancer and mechanisms of carcinogenesis. IARC Sci Publ 2004; 157: 289-97.

7. Leon ME, Peruga A, McNeill A, Kralikova E, Guha N, Minozzi S, et al. European Code against Cancer, $4^{\text {th }}$ Edition: Tobacco and cancer. Cancer Epidemiol 2015; 39(Suppl 1): 20-33.

8. Dirim A, Özkardeș H, Hasırcı E. Synchronous and metachronous secondary tumors of bladder cancer patients. Bulletin of Urooncology 2016; 15: 31-

9. Braakhuis BJ, Tabor MP, Kummer JA, Leemans CR, Brakenhoff RH. A genetic explanation of Slaughter's concept of field cancerization; evidence and clinical implications. Cancer Res 2003; 63: 1727-30.
10. Curtis RE, Freedman DM, Ron E, Ries LAG, Hacker DG, Edwards BK, et al . New malignancies among cancer survivors: SEER Cancer Registries, 1973-2000. National Cancer Institute, 2017.

11. Liu YY, Chen YM, Yen SH, Tsai CM, Perng RP. Multiple primary malignancies involving lung cancer-clinical characteristics and prognosis. Lung Cancer 2002; 35: 189-94.

12. Demandante CG, Troyer DA, Miles TP. Multiple primary malignant neoplasms: case report and a comprehensive review of the literature. Am J Clin Oncol 2003; 26: 79-83.

13. Aydiner A, Karadeniz A, Uygun K, Tas S, Tas F, Disci R, et al. Multiple primary neoplasms at a single institution: Differences between synchronous and metachronous neoplasms. Am J Clin Oncol 2000; 23: 364-70.

14. İmamoğlu Gi, Eren T, Şahin S, Yazılıtaş D, Altınbaş M, Esen R, et al. Çoklu primer tümörler-tek merkez deneyimi. Dicle Tıp Dergisi 2017; 44: 339-43.

15. Hayat MJ, Howlader N, Reichman ME, Edwards BK. Cancer statistics, trends, and multiple primary cancer analyses from the surveillance, epidemiology, and end results (SEER) program. Oncologist 2007; 12: 20-37.

16. Ueno M, Muto T, Oya M, Ota H, Azekura K, Yamaguchi T. Multiple primary cancer: an experience at the Cancer Institute Hospital with special reference to colorectal cancer. Int J Clin Oncol 2003; 8: 162-7.

17. Ray P, Sharifi R, Ortolano V, Guinan P. Involvement of the genitourinary system in multiple primary malignant neoplasms: A review. J Clin Oncol 1983; 1: 574-81.

18. Mak D, Corry J, Lau E, Rischin D, Hicks RJ. Role of FDGPET/CT in staging and follow-up of head and neck squamous cell carcinoma. Q J Nucl Med Mol Imaging 2011; 55: 487-99

19. Gokyer A, Kostek O, Hacioglu MB, Erdogan B, Kodaz H, Tutkmen E, et al. Clinical features of the patient with multiple primary tumors: Single center experience. North Clin İstanb 2017; 10: 43-51.

20. Artac M, Bozcuk H, Ozdogan M, Demiral AN, Sarper A, Samur M, et al. Different clinical features of primary and secondary tumors in patients with multiple malignancies. Tumori 2005; 91: 317-20.

21. Irimie A, Achimas-Cadariu P, Burz C, Puscas E. Multiple primary malignancies epidemiological analysis at a single tertiary institution. J Gastrointestin Liver Dis 2010; 19: 69-73.

22. Babacan NA, Aksoy S, Cetin B, Ozdemir NY, Benekli M, Uyeturk U, et al Multiple primary malignant neoplasms: Multi-center results from Turkey. J BUON 2012; 17: 770-5. 